\title{
PENALARAN SISWA DALAM MENYELESAIKAN MASALAH MATEMATIKA DITINJAU DARI KEMAMPUAN MATEMATIKA
}

\author{
Rizki Dwi Cahyanti \\ Pendidikan matematika, FMIPA, Universitas Negeri Surabaya \\ e-mail : rizkicahyanti@mhs.unesa.ac.id \\ Endah Budi Rahaju \\ Pendidikan matematika, FMIPA, Universitas Negeri Surabaya \\ e-mail: endahrahaju@unesa.ac.id
}

\begin{abstract}
Abstrak
Penalaran adalah proses berpikir dalam penarikan kesimpulan yang logis berdasarkan data dan bukti yang diperoleh melalui kegiatan mengumpulkan fakta, menganalisis data, menyusun dugaan, menyusun argumen. Tujuan penelitian ini adalah mendeskripsikan penalaran siswa dengan kemampuan matematika tinggi, sedang, dan rendah dalam menyelesaikan masalah matematika. Pendekatan yang digunakan pada penelitian ini adalah pendekatan kualitatif. Data penelitian diperoleh dari hasil tes kemampuan matematika, tes penalaran matematika, dan wawancara. Tes kemampuan matematika digunakan untuk mengelompokkan subjek sesuai dengan kemampuan matematikanya, tes penalaran matematika digunakan untuk mengetahui bagaimana penalaran siswa dalam menyelesaikan masalah matematika dan wawancara dilakukan untuk mendapatkan informasi yang lebih jelas mengenai penalaran siswa dalam mengerjakan tes penalaran matematika. Hasil penelitian menunjukkan bahwa (1) Siswa dengan kemampuan matematika tinggi mengumpulkan fakta dengan mendata hal yang diketahui dan ditanyakan, menganalisis data dengan membuat garis bantuan dan ilustrasi gambar, menguraikan masalah menjadi bagian-bagian secara rinci, mengajukan dugaan terkait solusi dan langkah-langkah penyelesaian, menyampaikan alasan pemilihan rumus yang digunakan dengan logis, menjelaskan langkah-langkah yang dilakukan dengan lancar, menarik kesimpulan berdasarkan langkah yang telah dilakukan serta menuliskan pada lembar pekerjaannya dan memeriksa kembali pekerjaannya untuk memastikan jawabannya. (2) Siswa dengan kemampuan matematika sedang mengumpulkan fakta dengan mendata hal yang diketahui dan ditanyakan, menganalisis data dengan membuat garis bantuan dan ilustrasi gambar, menguraikan masalah menjadi bagian-bagian namun tidak secara rinci, mengajukan dugaan terkait langkah-langkah penyelesaian, menyampaikan argumen yang kurang logis terkait alasan pemilihan rumus yang digunakan, menjelaskan langkah-langkah yang dilakukan dengan lancar, menarik kesimpulan berdasarkan langkah yang telah dilakukan tetapi tidak menuliskan pada lembar pekerjaannya dan memeriksa kembali pekerjaannya untuk memastikan jawabannya. (3) Siswa dengan kemampuan matematika rendah tidak mampu menyelesaikan masalah matematika. Dalam mengumpulkan fakta, ia mendata hal yang diketahui dan ditanyakan, tidak menguraikan masalah menjadi bagian-bagian secara rinci, dugaan terkait langkah-langkah penyelesaian yang diajukan tidak tepat, memberikan argumen yang kurang logis terkait alasan pemilihan rumus yang digunakan, menjelaskan langkah-langkah yang dilakukan dengan lancar, menarik kesimpulan berdasarkan langkah yang telah dilakukan tetapi tidak menuliskan pada lembar pekerjaannya dan memeriksa kembali pekerjaannya akan tetapi tidak teliti sehingga solusi penyelesaian yang diperoleh masih belum tepat.
\end{abstract}

Kata Kunci: Penalaran, Masalah Matematika, Kemampuan Matematika.

\begin{abstract}
Reasoning is the process of thinking in drawing logical conclusions based on data and evidence obtained through the activity of collecting facts, analyzing data, compiling allegations, compiling arguments. The purpose of this study is describing the reasoning of students with high, moderate, and low mathematical abilities in solving mathematical problems. The approach used in this study is a qualitative approach. The research data was obtained from the results of mathematical abilities test, mathematical reasoning tests, and interviews. Mathematical ability tests are used to group subjects according to their mathematical abilities, mathematical reasoning tests are used to find out how students' reasoning in solving mathematical problems and interviews is conducted to get in-depth and clear information about students' reasoning in working on mathematical reasoning tests. The results of the study show that (1) Students with high mathematical abilities
\end{abstract}


collect facts by recording things that known and asked, analyzing data by making help lines and illustrating images, describing problems in detail, presenting allegations related to solutions and steps, conveying the reason for choosing a formula logically, explaining steps taken smoothly, drawing conclusions based on the steps taken and writing on the work sheet and re-checking the work to ensure the answer. (2) Students with moderate mathematical abilities collect facts by recording things that known and asked, analyzing data by making help lines, didn't describe the problem into parts in detail, proposing allegations related to steps, conveying arguments that less logical related to the reasons for choosing the formula, explaining the steps taken smoothly, drawing conclusions based on the steps but not writing on the work sheet and re-checking the work to ensure the answer. (3) Students with low mathematical abilities unable to solved mathematical problems. In collecting facts, he records things that known and asked, didn't describe the problem into parts in detail, the allegations related to steps were incorrect, give a less logical argument related to the reason for choosing the formula, explain the steps carried out smoothly, drawing conclusions based on the steps but not writing on the work sheet and re-checking the work but not carefully so solutions obtained were still not appropriate.

Keywords: Reasoning, Mathematical Problems, Mathematical Ability.

\section{PENDAHULUAN}

Pendidikan merupakan suatu upaya untuk memberikan pengetahuan kepada seseorang dengan tujuan agar orang tersebut mampu menghadapi perubahan akibat adanya kemajuan ilmu pengetahuan dan teknologi (IPTEK). Salah satu mata pelajaran yang berperan dalam perkembangan IPTEK adalah matematika. Matematika perlu diajarkan kepada semua peserta didik mulai dari sekolah dasar untuk membekali peseta didik dengan sikap logis, kritis, cermat dan teliti, jujur, bertanggung jawab, dan tidak mudah menyerah dalam menyelesaikan masalah (Permendikbud, 2016).

Peraturan Menteri Pendidikan dan Kebudayaan No. 21 tahun 2016 tentang Standart Isi Pendidikan Dasar dan Menengah menyatakan bahwa pada sekolah menengah siswa dituntut untuk menunjukkan keterampilan menalar, mengolah, dan menyaji. Di sisi lain, NCTM (2000) juga menetapkan lima standar keterampilan dalam pembelajaran matematika yaitu pemecahan masalah, penalaran dan pembuktian, komunikasi, koneksi dan representasi. Kedua pernyataan tersebut menunjukkan bahwa penalaran menjadi salah satu keterampilan yang harus dikuasai siswa dalam pembelajaran matematika. Penalaran dalam matematika disebut juga sebagai penalaran matematika atau mathematical reasoning.

Hasil penelitian yang dilakukan Siskawati (2015) menunjukkan penalaran siswa dapat dilihat berdasarkan kemampuannya dalam memecahkan masalah matematika. Pernyataan tersebut menunjukkan bahwa aktivitas siswa dalam menyelesaikan masalah dapat digunakan untuk melihat bagaimana penalaran siswa. Untuk menemukan solusi penyelesaian masalah tersebut siswa dapat menggunakan pengetahuan sebelumnya dan membangun pengetahuan baru dari pengetahuan yang telah dimiliki (NCTM, 2000: 52).
Penalaran sendiri dapat didefinisikan sebagai proses berpikir dalam menarik kesimpulan ( Permana \& Sumarmo, 2007: 116). Sejalan dengan itu, Suharnan (2005: 6) mendefinisikan penalaran sebagai sistem penarikan kesimpulan berdasarkan aturan-aturan logika. Penalaran dibedakan menjadi dua macam yakni penalaran induktif dan penalaran deduktif. Penalaran induktif adalah sistem penarikan kesimpulan dari hal-hal khusus ke halhal umum. Sedangkan penalaran deduktif adalah sistem penarikan kesimpulan dari hal-hal umum ke hal-hal khusus.

Matematika dan penalaran merupakan dua hal yang tidak dapat dipisahkan. Pernyataan tersebut sesuai dengan NCTM (2000: 262) yang menyatakan bahwa "Reasoning is an integral part of doing mathematics". Hal tersebut menunjukkan bahwa penalaran merupakan bagian yang tak terpisahkan dari matematika. Handayani (2013) berpendapat bahwa penalaran tidak hanya dibutuhkan siswa pada saat pembelajaran matematika ataupun mata pelajaran lainnya namun sangat dibutuhkan siswa ketika menyelesaikan masalah dan mengambil keputusan dalam kehidupan sehari-hari. Melalui penalaran, siswa dapat mengajukan dugaan, menyusun bukti, melakukan manipulasi terhadap permasalahan matematika serta menarik kesimpulan dengan benar dan tepat (Handayani, 2013). Sehingga kemampuan penalaran sangat penting dan dibutuhkan dalam mempelajari matematika.

Walaupun penalaran itu penting, namun kenyataannya kemampuan penalaran siswa di Indonesia masih belum maksimal. Keadaan tersebut dapat dilihat berdasarkan fakta-fakta yang terjadi di lapangan. Hasil TIMSS 2015 mengungkapkan bahwa Indonesia menduduki ranking 45 dari 50 negara dengan pencapaian skor matematika 379 poin serta diungkap bahwa kemampuan penalaran matematis siswa di Indonesia masih lemah dengan presentase domain kognitif level penalaran siswa sebesar 20\% (Rahmawati, 2016). Menurut 
Rahmawati (2016) siswa di Indonesia perlu penguatan dalam beberapa kemampuan, salah satunya kemampuan menarik kesimpulan.

Menurut Robbins (2013: 52), kemampuan adalah kapasitas individu untuk melakukan berbagai tugas dalam suatu pekerjaan. Kemampuan dibedakan menjadi dua macam yakni kemampuan intelektual dan kemampuan fisik. Kemampuan intelektual adalah kapasitas seseorang untuk melakukan aktivitas mental seperti berpikir, bernalar, dan memecahkan masalah. Sementara itu, kemampuan fisik adalah kapasitas seseorang untuk melakukan tugas yang menuntut stamina, ketangkasan, kekuatan dan kakteristik serupa (Robbins, 2013: 52-53). Berdasarkan pendapat tersebut dapat disimpulkan bahwa kemampuan intelektual berkaitan dengan penalaran dan pemecahan masalah. Dalam penelitian ini, kemampuan intektual yang dimaksud adalah kemampuan intelektual dalam bidang matematika atau disebut dengan kemampuan matematika.

Pada penelitian ini, kemampuan matematika adalah kapasitas seseorang untuk menyelesaikan soal matematika. Kemampuan matematika siswa digolongkan ke dalam tiga kategori yakni kemampuan matematika tinggi, kemampuan matematika sedang dan kemampuan matematika rendah. Penggolongan tersebut dilakukan berdasarkan skor tes kemampuan matematika yang diperoleh siswa.

Perbedaan kemampuan matematika siswa memungkinkan adanya perbedaan terkait penalaran dan pemecahan masalah matematika. Hasil penelitian Isro'il (2017) menyatakan bahwa kemampuan matematika siswa berpengaruh terhadap proses pemecahan masalah yang dilakukannya. Sementara itu hasil penelitian Alfiani (2016) menyatakan bahwa siswa dengan kemampuan matematika yang relatif sama menunjukkan adanya persamaan penalaran saat memecahkan masalah matematika. Berdasarkan hasil penelitian tersebut, perbedaan kemampuan matematika siswa memungkinkan adanya perbedaan penalaran dalam menyelesaikan masalah matematika.

Berdasarkan uraian di atas, peneliti tertarik untuk melakukan penelitian yang berjudul "Penalaran Siswa dalam Menyelesaikan Masalah Matematika Ditinjau dari Kemampuan Matematika”.

\section{METODE}

Pendekatan dalam penelitian ini adalah pendekatan kualitatif. Sementara jenis penelitiannya adalah deskriptif kualitatif yang bertujuan mendeskripsikan penalaran siswa dalam menyelesaikan matematika ditinjau dari kemampuan matematika. Instrumen utama dalam penelitian ini adalah peneliti sendiri sedangkan instrumen pendukungnya terdiri dari tes kemampuan matematika, tes penalaran matematika dan wawancara.

Penelitian ini dilaksanakan di kelas VIII-F SMP Negeri 32 Surabaya dengan banyak siswa sejumlah 34 siswa. Dari 34 siswa dipilih 3 siswa dengan kemampuan matematika tinggi, sedang, dan rendah sebagai subjek penelitian. Teknik analisis data yang dilakukan meliputi analisis hasil tes kemampuan matematika, penalaran matematika dan wawancara.

\section{HASIL DAN PEMBAHASAN}

Indikator penalaran yang digunakan dalam penelitian ini meliputi mengumpulkan fakta, menganalisis data, menyusun dugaan, menyusun argumen, menarik kesimpulan yang logis dan memvalidasi kesimpulan yang logis. Berikut paparan mengenai hasil dan pembahasan pada penelitian ini.

Berikut merupakan penalaran siswa dengan kemampuan matematika tinggi, sedang dan rendah dalam menyelesaikan masalah matematika.

a. Pada aktivitas mengumpulkan fakta, siswa dengan kemampuan matematika tinggi mendata hal-hal yang diketahui dan ditanyakan dengan cara membaca soal dan memperhatikan gambar pada soal. Hal tersebut juga dilakukan oleh siswa dengan kemampuan sedang dan rendah. Informasi yang dikumpulkan oleh ketiga siswa dengan kemampuan matematika tinggi, sedang dan rendah terkait hal yang diketahui cenderung sama. Informasi yang diperoleh siswa dengan kemampuan matematika tinggi terkait hal yang diketahui yaitu sisi persegi $14 \mathrm{~cm}$ dan $p h i \frac{22}{7}$. Informasi yang diperoleh siswa dengan kemampuan matematika sedang terkait hal yang diketahui yaitu diameter lingkaran $14 \mathrm{~cm}$ dan phi $\frac{22}{7}$ sedangkan informasi yang diperoleh siswa dengan kemampuan matematika rendah terkait hal yang diketahui yaitu pola persegi dan segitiga, phi $\frac{22}{7}$, diameter dan jari-jari lingkaran. Sementara untuk informasi yang dikumpulkan oleh ketiga siswa dengan kemampuan matematika tinggi, sedang dan rendah terkait hal yang ditanyakan cenderung sama yaitu luas daerah/ pola yang diarsir. Ketiga siswa menuliskan informasi yang diperoleh pada lembar jawaban, dan menyampaikan informasi yang diperoleh menggunakan kalimatnya sendiri dengan lancar.

b. Pada aktivitas menganalisis data, siswa dengan kemampuan matematika tinggi menggunakan garis bantu dan ilustrasi gambar untuk menguraikan inti permasalahan. Siswa dengan kemampuan matematika sedang juga melakukan hal serupa. Sementara siswa dengan kemampuan matematika rendah tidak menguraikan inti permasalahan. Dengan menguraikan 
inti permasalahan, siswa dengan kemampuan matematika tinggi dan sedang memperoleh informasi bahwa gambar tersebut tersusun dari 4 bagian dengan pola yang sama. Dalam menganalisis data siswa dengan kemampuan matematika tinggi sedang dan rendah ketiganya memperoleh fakta lain yaitu jari-jari lingkaran senilai $7 \mathrm{~cm}$. Siswa dengan kemampuan matematika tinggi dan sedang keduanya menyebutkan bahwa gambar pada soal tersusun oleh bangun persegi dan lingkaran. Sementara siswa dengan kemampuan rendah menyebutkan bahwa gambar pada soal tersusun oleh bangun persegi, lingkaran dan oval. Siswa dengan kemampuan matematika tinggi menyebutkan terdapat hubungan diantara kedua bangun tersebut yaitu panjang diameter lingkaran sama dengan sisi persegi. Sementara siswa dengan kemampuan sedang dan rendah menyebutkan bahwa hubungan diatara bangun penyusun gambar berkaitan dengan luas yang diarsir. Berdasarkan fakta yang telah terkumpul, ketiga siswa dengan kemampuan matematika tinggi, sedang dan rendah memperkirakan bahwa informasi tersebut cukup untuk menyelesaikan masalah matematika.

c. Pada aktivitas menyusun dugaan, siswa dengan kemampuan matematika tinggi mengajukan dugaan terkait solusi dari permasalahan dan langkah-langkah penyelesaian yang akan dilakukan. Sementara siswa dengan kemampuan matematika sedang dan rendah hanya mengajukan dugaan terkait langkah-langkah penyelesaian. Siswa dengan kemampuan matematika tinggi menduga solusi dari permasalahan bernilai positif dikarenakan luas tidak mungkin bernilai negatif. Langkah-langkah yang akan dilakukan siswa dengan kemampuan matematika tinggi untuk menyelesaikan permasalahan yaitu mencari luas yang diarsir pada seperempat bagian terlebih dahulu kemudian hasilnya dikalikan 4. Hal tersebut juga disampaikan oleh siswa dengan kemampuan matematika sedang. Namun, rumus yang digunakan keduanya berbeda. Siswa dengan kemampuan matematika tinggi menggunakan rumus $2 \times \pi \times \frac{1}{4} \times r^{2}$ kemudian dikurangi dengan luas persegi sedangkan siswa dengan kemampuan matematika sedang menggunakan rumus $\frac{1}{2} \times \pi \times r^{2}$ kemudian dikurangi dengan luas persegi. Sementara dalam mengajukan dugaan terkait langkah-langkah penyelesaian siswa dengan kemampuan matematika rendah melakukan kesalahan, sehingga rumus yang diajukan tidak tepat yaitu $\pi \times d \times d$ kemudian dikurangi dengan luas persegi. Siswa dengan kemampuan matematika tinggi, sedang maupun rendah menjelaskan langkah-langkah yang akan dilakukan untuk menyelesaikan permasalahan dengan lancar. d. Pada aktivitas menyusun argumen, siswa dengan kemampuan matematika tinggi memberikan argumen yang logis terkait alasan memilih rumus yang akan digunakan untuk menyelesaikan permasalahan dengan lancar. Sementara siswa dengan kemampuan matematika sedang dan rendah memberikan argumen yang tidak logis terkait alasan memilih rumus yang akan digunakan untuk menyelesaikan permasalahan. Alasan yang diungkapkan siswa dengan kemampuan matematika tinggi yaitu pada seperempat bagian terdapat dua buah seperempat lingkaran dan persegi. Sehingga, untuk mencari luas daerah yang diarsir pada bagian tersebut, dicari luas seperempat lingkaran terlebih dahulu. Kemudian hasilnya dikalikan 2 karena terdapat 2 buah seperempat lingkaran dan langkah terakhir dikurangi dengan luas persegi. Siswa dengan kemampuan matematika tinggi menerapkan dan menjelaskan langkah-langkah penyelesaian sesuai yang telah ditentukan secara runtut. Untuk penjelasan setiap langkah yang dilakukan siswa dengan kemampuan matematika tinggi seperti dari $\frac{22}{7} \times \frac{1}{4} \times 7^{2}$ diperoleh hasil $\frac{77}{2}$, selanjutnya dikalikan 2 hasilnya adalah 77 . Kemudian dikurangi dengan luas persegi yaitu 49 hasilnya 28 dan untuk mencari luas keseluruhan daerah yang diarsir 28 dikalikan 4 sama dengan 112. Alasan yang diungkapkan siswa dengan kemampuan matematika sedang yaitu $\frac{1}{2}$ merupakan perbandingan bagian yang diarsir terhadap bagian yang diarsir lalu dikalikan luas lingkaran karena daerah yang diarsir berbentuk lingkaran. Siswa dengan kemampuan matematika sedang menerapkan langkah-langkah penyelesaian sesuai yang telah ditentukan. Siswa dengan kemampuan matematika sedang menjelaskan langkah-langkah penyelesaian dengan lancar. Untuk penjelasan setiap langkah yang dilakukan siswa dengan kemampuan matematika sedang seperti dari $\frac{1}{4} \times \frac{22}{7} \times$ $7^{2}$, diperoleh hasil 77 , kemudian dikurangi dengan luas persegi yaitu 49 hasilnya sama dengan 28. Untuk mencari total luas daerah yang diarsir 28 dikalikan 4 sama dengan 112. Sementara alasan yang diungkapkan siswa dengan kemampuan matematika rendah yaitu dikarenakan adanya lingkaran dan daerah yang diarsir sebesar $\frac{3}{4}$ bagian lingkaran untuk mencari luasnya menggunakan rumus luas lingkaran dikalikan dengan $\frac{3}{4}$ kemudian dikurangi luas persegi. Siswa dengan kemampuan matematika rendah menerapkan langkahlangkah penyelesaian sesuai yang telah ditentukan. Untuk penjelasan setiap langkah yang dilakukan siswa dengan kemampuan matematika rendah seperti dari $\frac{3}{4} \times \frac{22}{7} \times 14 \times 14$ diperoleh hasil 462 , kemudian 
dikurangi dengan luas persegi yaitu 196 hasilnya sama dengan 266.

e. Pada aktivitas menarik kesimpulan yang logis, siswa dengan kemampuan matematika tinggi, sedang maupun rendah membuat suatu pernyataan berdasarkan langkah-langkah penyelesaian yang dilakukan. Siswa dengan kemampuan matematika tinggi mengungkapkan berdasarkan perhitungan yang dilakukan luas daerah yang diarsir pada seperempat bagian adalah 28, sehingga untuk luas keseluruhan daerah yang diarsir adalah 112 yang diperole dari $28 \times 4$. Berdasarkan hal tersebut siswa dengan kemampuan matematika tinggi menyimpulkan bahwa "luas daerah yang diarsir bernilai $112 \mathrm{~cm}^{2}$ " dan menuliskan kesimpulan yang dibuat pada lembar pekerjaannya. Siswa dengan kemampuan matematika tinggi menyampaikan kesimpulan yang dibuat dengan lancar. Siswa dengan kemampuan matematika sedang mengungkapkan berdasarkan perhitungan yang dilakukan total luas daerah yang diarsir adalah 112, sehingga kesimpulannya luas daerah yang diarsir adalah $112 \mathrm{~cm}^{2}$. Sementara Siswa dengan kemampuan matematika rendah mengungkapkan berdasarkan perhitungan yang dilakukan diperoleh hasil akhir adalah 266, sehingga kesimpulannya luas daerah yang diarsir adalah $266 \mathrm{~cm}^{2}$. Siswa dengan kemampuan matematika sedang dan rendah tidak menuliskan kesimpulan yang dibuat pada lembar pekerjaannya.

f. Pada aktivitas memvalidasi kesimpulan yang logis, baik siswa dengan kemampuan matematika tinggi, sedang maupun rendah memeriksa kembali setiap langkah yang dilakukan. Baik siswa dengan kemampuan matematika tinggi, sedang maupun rendah memastikan kebenaran solusi yang diperoleh dengan cara memeriksa pekerjaannya dan menghitung ulang setiap langkah penyelesaiannya. Solusi yang diperoleh siswa dengan kemampuan matematika tinggi dan sedang bernilai benar. Sementara dalam memvalidasi kesimpulan yang logis siswa dengan kemampuan matematika rendah kurang teliti sehingga tidak menyadari bahwa rumus yang digunakan tidak sesuai. Akibatnya, solusi penyelesaian yang diperoleh siswa dengan kemampuan rendah masih belum tepat.

\section{Pembahasan}

Berdasarkan hasil dan analisis data penelitian di atas menunjukkan bahwa penalaran dapat ditelaah melalui pemecahan masalah matematika dan ketiga siswa menunjukkan penalaran yang berbeda dalam menyelesaikan masalah matematika. Hal ini sesuai dengan Solso (2008) yang menyatakan penalaran terlibat di dalam proses pemecahan masalah dikarenakan memang beberapa bentuk penalaran biasanya merupakan bagian dari pemecahan masalah itu sendiri. Selain itu juga sejalan dengan Rosita (2014) yang berpendapat bahwa kemampuan bernalar dapat berpengaruh terhadap kemahiran siswa dalam memecahkan masalah matematika. Pada hasil dan analisis data terdapat persamaan dan perbedaan penalaran antara siswa dengan kemampuan matematika tinggi, sedang, dan rendah dalam menyelesaikan masalah matematika yang di berikan.

Hasil dan analisis data menunjukkan bahwa ketiga siswa cenderung sama dalam aktivitas mengumpulkan fakta, menarik kesimpulan yang logis, dan memvalidasi kesimpulan yang logis. Ketiga siswa mengumpulkan fakta dengan mendata hal-hal yang diketahui dan ditanya yang diperoleh memalui membaca soal dan mengamati gambar. Dalam menarik kesimpulan ketiga siswa membuat kesimpulan berdasarkan perhitungan yang dilakukan. Dalam menarik kesimpulan siswa dengan kemampuan matematika sedang dan rendah tidak menuliskan kesimpulan yang dibuat pada lembar pekerjaannya. Dalam memvalidasi kesimpulan yang logis ketiga siswa memastikan kebenaran solusi yang diperoleh dengan memeriksa kembali pekerjaannya dan menghitung ulang setiap langkah yang dilakukan. Namun, siswa dengan kemampuan rendah kurang teliti dalam memeriksa kembali pekerjaannya sehingga solusi yang diperoleh masih belum tepat akibat kesalahan dalam mengajukan dugaan penyelesaian. Sementara itu, terdapat perbedaan pada ketiga subjek dalam aktivitas menganalisis data, menyusun dugaan dan menyusun argumen. Siswa dengan kemampuan matematika tinggi dan sedang dalam menganalisis data menggunakan garis bantu dan ilustrasi gambar untuk menguraikan inti permasalahan, sedangkan siswa dengan kemampuan matematika rendah tidak menguraikan inti permasalahan. Dalam menyusun dugaan siswa dengan kemampuan matematika tinggi dan sedang mengajukan dugaan penyelesaian yang sama yaitu dengan cara mencari luas seperempat bagian yang diarsir terlebih dahulu kemudian dikalikan 4. Sementara siswa dengan kemampuan rendah mengajukan dugaan penyelesaian yang berbeda yaitu dengan mencari luas daerah lingkaran yang diarsir kemudian dikurangi dengan luas persegi. Selain itu, dalam menyusun dugaan siswa dengan kemampuan matematika tinggi juga mengajukan dugaan terkait solusi penyelesaian. Dalam menyusun argumen siswadengan kemampuan matematika tinggi memberikan argumen yang logis terkait alasan pemilihan rumus. Sementara siswa dengan kemampuan matematika tinggi dan sedang memberikan argumen yang kurang logis terkait alasan pemilihan rumus. Ketiga siswa menerapkan langkah penyelesaian sesuai dengan yang telah ditentukan sebelumnya dan mampu menjelaskan setiap langkah yang dilakukan dengan lancer. 


\section{PENUTUP}

\section{Simpulan}

Berdasarkan hasil analisis data yang telah dilakukan maka simpulan penalaran siswa dalam dalam menyelesaikan masalah matematika ditinjau dari kemampuan matematika adalah sebagai berikut.

1. Penalaran siswa dengan kemampuan matematika tinggi dalam menyelesaikan masalah matematika

Siswa dengan kemampuan matematika tinggi dalam mengumpulkan fakta mampu menyebutkan dan menuliskan informasi yang diperoleh dari membaca soal dan mengamati gambar. Dalam menganalisis data siswa dengan kemampuan matematika tinggi menguraikan masalah menjadi bagian-bagian secara rinci yang dimulai dengan membuat garis bantuan dan ilustrasi gambar. Selain itu, dengan menganalisis data siswa dengan kemampuan matematika tinggi mengidentifikasi secara jelas pola, bangun penyusun gambar pada soal serta hubungannya. Siswa dengan kemampuan matematika tinggi menyebutkan bangun penyusun gambar serta hubungannya dengan lancar. Siswa dengan kemampuan matematika tinggi memperoleh informasi yang cukup untuk menyelesaikan masalah matematika. Dalam menyusun dugaan siswa dengan kemampuan matematika tinggi mengajukan dugaan terkait solusi penyelesaian dan langkah-langkah penyelesaian yang akan digunakan dengan lancar. Dalam menyusun argumen siswa dengan kemampuan matematika tinggi menyampaikan argumen yang logis terkait alasan pemilihan rumus yang digunakan untuk menyelesaikan permasalahan dengan runtut dan lancar. Siswa dengan kemampuan matematika tinggi menjelaskan setiap langkah penyelesaian yang dilakukan dengan lancar. Dalam menarik kesimpulan yang logis, siswa dengan kemampuan matematika tinggi membuat kesimpulan berdasarkan langkah-langkah penyelesaian yang telah dilakukan. Siswa dengan kemampuan matematika tinggi menyebutkan dan menuliskan kesimpulan yang telah dibuat dalam lembar pekerjaanya. Solusi penyelesaian yang diperoleh siswa dengan kemampuan matematika tinggi bernilai benar. Dalam memvalidasi kesimpulan yang logis, siswa dengan kemampuan matematika tinggi memastikan kebenaran solusi yang diperoleh dengan cara memeriksa kembali dan menghitung ulang setiap langkah penyelesaian yang dilakukan.

2. Penalaran siswa dengan kemampuan matematika sedang dalam menyelesaikan masalah matematika Siswa dengan kemampuan matematika sedang dalam mengumpulkan fakta mampu menyebutkan dan menuliskan informasi yang diperoleh dari membaca soal. Dalam menganalisis data, siswa dengan kemampuan matematika sedang menguraikan masalah menjadi bagian-bagian namun tidak secara rinci. Hal tersebut ditunjukkan ketika menganalisis data siswa dengan kemampuan matematika sedang membuat garis bantuan dan ilustrasi gambar namun tidak mengidentifikasi secara jelas hubungan antara bangun pada gambar. Siswa dengan kemampuan matematika sedang menyebutkan bangun penyusun gambar serta hubungannya dengan lancar. Siswa dengan kemampuan matematika sedang memperoleh informasi yang cukup untuk menyelesaikan masalah matematika. Dalam menyusun dugaan siswa dengan kemampuan matematika sedang mengajukan dugaan terkait langkah-langkah penyelesaian yang akan digunaka. Dalam menyusun argumen siswa dengan kemampuan matematika sedang menyampaikan argumen yang kurang logis terkait alasan pemilihan rumus yang digunakan untuk menyelesaikan permasalahan. Siswa dengan kemampuan matematika sedang menjelaskan setiap langkah penyelesaian yang dilakukan dengan lancar. Dalam menarik kesimpulan yang logis, siswa dengan kemampuan matematika sedang membuat kesimpulan berdasarkan langkah yang telah dilakukan tetapi tidak menuliskan pada lembar pekerjaannya. Solusi penyelesaian yang diperoleh siswa dengan kemampuan matematika sedang bernilai benar. Dalam memvalidasi kesimpulan yang logis, siswa dengan kemampuan matematika sedang memastikan kebenaran solusi yang diperoleh dengan cara memeriksa kembali setiap langkah penyelesaian yang dilakukan.

3. Penalaran siswa dengan kemampuan matematika rendah dalam menyelesaikan masalah matematika

Siswa dengan kemampuan matematika rendah tidak mampu menyelesaikan masalah matematika. Siswa dengan kemampuan matematika rendah mengumpulkan fakta mampu menyebutkan dan menuliskan informasi yang diperoleh dari membaca soal. Dalam menganalisis data, siswa dengan kemampuan matematika rendah tidak menguraikan masalah menjadi bagian-bagian secara rinci. Siswa dengan kemampuan matematika rendah menyebutkan bangun penyusun gambar akan tetapi ada beberapa bangun yang tidak sesuai. Dalam menyusun dugaan, siswa dengan kemampuan matematika rendah mengajukan dugaan terkait langkah-langkah penyelesaian akan tetapi dugaan penyelesaian yang diajukan tidak tepat. Dalam menyusun argumen siswa dengan kemampuan matematika rendah menyampaikan argumen yang kurang logis terkait alasan pemilihan rumus yang digunakan. Siswa dengan kemampuan matematika rendah menjelaskan setiap langkah penyelesaian yang dilakukan dengan lancar. 
Dalam menarik kesimpulan yang logis, siswa dengan kemampuan matematika rendah membuat kesimpulan berdasarkan langkah yang telah dilakukan tetapi tidak menuliskan pada lembar pekerjaannya. Solusi penyelesaian yang diperoleh siswa dengan kemampuan matematika rendah masih belum tepat akibat kesalahan yang dilakukan dalam menentukan dugaan penyelesaian. Dalam memvalidasi kesimpulan yang logis, siswa dengan kemampuan matematika rendah memastikan kebenaran solusi yang diperoleh dengan cara memeriksa kembali pekerjaannya akan tetapi tidak teliti dalam memeriksa sehingga solusi penyelesaian yang diperoleh masih belum tepat.

\section{Saran}

Berdasarkan hasil penelitian yang telah dilakukan peneliti memberikan saran sebagai berikut.

1. Hasil penelitian menunjukkan bahwa dalam proses bernalar siswa dengan kemampuan matematika sedang dan kemampuan matematika rendah masih belum maksimal pada beberapa indikator seperti menyusun dugaan dan menyusun argumen. Berdasarkan informasi tersebut sebaiknya guru lebih memperhatikan siswa dengan kemampuan matematika sedang maupun rendah khususnya pada kedua indikator tersebut. Adapun hal yang dapat dilakukan yaitu melatih kemampuan bernalar siswa dengan memberikan soal matematika yang dapat mendorong siswa untuk bernalar. Selain itu, melatih siswa untuk menyampaikan argumen terkait langkahlangkah penyelesaian dan mengoreksi apabila ada kesalahan. Dengan begitu diharapkan kemampuan penalaran siswa dapat meningkat.

2. Hasil penelitian menunjukkan data wawancara dari beberapa siswa kurang mendalam. Adapun data yang dimaksud yaitu data siswa dengan kemampuan matematika sedang dan siswa dengan kemampuan matematika rendah pada indikator menganalisis data terkait pola dan hubungan serta data siswa dengan kemampuan matematika tinggi dan siswa dengan kemampuan matematika sedang pada indikator memvalidasi kesimpulan yang logis. Hal tersebut terjadi akibat situasi dan kondisi pelaksanaan wawancara yang kurang mendukung. Wawancara dilaksanakan di teras masjid pada waktu yang berdekatan dengan waktu pulang sekolah sehingga situasi dan kondisi pada saaat wawancara kurang kondusif. Hal tersebut berdampak pada peneliti dan siswa saat melaksanakan wawancara seperti ada beberapa pertanyaan yang terlewat untuk diajukan pada beberapa indikator. Berdasarkan informasi tersebut bagi peneliti lain yang akan melakukan penelitian disarankan untuk melaksanakan tes maupun wawancara di tempat dan waktu yang memungkinkan situasi dan kondisi pelaksanaan penelitian dapat kondusif.

\section{DAFTAR PUSTAKA}

Alfiani. 2016. Penalaran Siswa Smp Dalam Memecahkan Masalah Matematika Ditinjau Dari Jenis Kelamin. Tesis tidak diterbitkan. Surabaya: PPs Universitas Negeri Surabaya.

Handayani, Aprilia Dwi. 2013. "Penalaran Kreatif Matematis". Jurnal Pengajaran MIPA, Volume 18, Nomor 2, hal: 161-166.

Isro'il, Ahmad. 2017. Profil Berpikir Siswa SMP dalam Menyelesaikan Masalah Matematika Ditinjau dari Kemampuan Matematika. Tesis tidak diterbitkan. Surabaya: PPs Universitas Negeri Surabaya.

Kemendikbud. 2016. Peraturan No. 21 tentang Standart Isi Pendidikan Dasar dan Menengah. Jakarta: Kementerian Pendidikan dan Kebudayaan

National Council of Teachers of Mathematics. 2000. Principles and Standards for School Mathematics. Reston, VA: NCTM.

Permana, Y., \& Sumarmo, U. 2007. "Mengembangkan Kemampuan Penalaran dan Koneksi Matematik Siswa SMA Melalui Pembelajran Berbasis Masalah". Educationist, Vol.I No.2/Juli 2007.

Robbins, Stephen P. J., \& Timothy, A. 2013. Organizational Behavior Fifteenth Edition. New Jersey: Pearson Education, Inc.,

Rosita, Citra D. 2014. "Kemampuan Penalaran dan Komunikasi Matematis: Apa, Mengapa, dan Bagaimana Ditingkatkan pada Mahasiswa". Jurnal Euclid, Vol.1 No. 1.

Solso, R.L, Maclin, O.H.M, Kimberly Maclin. 2008. Psikologi Kognitif Edisi Kedelapan (Terjemahan Mikael Rahardanto dan Kristianto Batuadji). Jakarta: Erlangga.

Suharnan. 2005. Psikologi Kognitif. Surabaya: Srikandi. 